Original Article

\title{
Study on Unnatural Death Patterns in Dhaka City
}

\author{
*Md. Belayet Hossain Khan ${ }^{1}$, Md. Mosharraf Hossain ${ }^{2}$ \\ ${ }^{1}$ Md. Belayet Hossain Khan' Assistant Professor, Dept. of Forensic Medicine \\ Sir Salimullah Medical College \\ (Ex Lecture, Forensic Medicine, Dhaka Medical College, Dhaka) \\ ${ }^{2}$ Md. Mosharraf Hossain ${ }^{2}$ Senior Lecturer, Dept. of Forensic Medicine \\ Nightingale Medical College, Ashulia, Dhaka \\ *Corresponding Author
}

\begin{abstract}
Unnatural deaths are the deaths which are caused by any means other than any disease ${ }^{1}$. Unnatural death is an indicator of social and mental health. This retrospective study was done to ascertain the pattern of unnatural deaths, whose autopsies were performed by Forensic medicine dept. of Dhaka Medical College from $1^{\text {st }}$ Jan, 1996 to $31^{\text {st }}$ Dec, 2000. A total 10436 death recorded were analysed to see their age, sex etc. The study revealed that total number of unnatural deaths were 9413, out of them males were higher than females ( M- 75.78\% \& F24.22\%). Results showed that Accidental deaths were 77.22\%, Homicidal deaths were $14.02 \%$ and Suicidal deaths were $10.76 \%$. Accidental \& Homicidal deaths were more common in male, whereas suicidal deaths were more common in female. This study suggest an extensive studies to formulate strategies to prevent those unnatural death to improve the situation.
\end{abstract}

Key Words: Unnatural Death Patterns, Suicidal, Accidental

\section{Introduction}

Now Uncontrolled Population is a burning problem in our country. It is increasing day by day without any development of socioeconomic condition. Our natural growth rate is $2.16 \%{ }^{2}$. Due to increasing number of population, our life becoming complex \& threatened. Due to poor socioeconomic condition, development of communication, transport \& technology, the number of crimes also becoming higher for the last few years. Unnatural death is one of the indicators of the level of social \& mental health ${ }^{3}$. Accidents have their own natural history and follow the same epidemiological pattern as any other deaths from disease that is the agent, the host and the environment interacting together to produce injury or damage ${ }^{4}$. They occur more frequently in certain age group, sex etc. Causing more mortality, morbidity and disability rate. Types of accidental deaths include road traffic accidents, domestic accidents, industrial accidents, railway accident, violences etc. Accidental deaths are more common among all other categories of unnatural deaths in home and abroad. This study is an attempt to explore the pattern of unnatural deaths in Dhaka City, referred to the Forensic Medicine dept. of Dhaka Medical College for Postmortem examinations.

\section{Materials and Methods}

Reports of unnatural deaths examined in the department of Forensic Medicine, Dhaka Medical College from $1^{\text {st }}$ Jan. 1996 to $31^{\text {st }}$ Dec, 2000, were the source of data. A total 10436 deaths recorded analysed to find out the pattern of unnatural deaths to formulate strategies to prevent and control the number of unnatural deaths. Data were collected and recorded purposively from retrospective records of postmortem examinations and processed by Computer.

\section{Results}

Out of 10436 deaths recorded at DMC Morgue, total number of unnatural deaths were 9413 , out of 
them 7080(75.22\%) were Accidental deaths, $1320(14.02 \%)$ were Homicidal deaths \& 1013(10.76\%) were Suicidal deaths.

Table I: Nature of death by age

\begin{tabular}{lccc}
\multicolumn{4}{c}{$\mathbf{n = 9 4 1 3}$} \\
\hline Age in years & \multicolumn{3}{c}{ Nature of death } \\
& Accidental & Homicidal & Suicidal \\
\hline $0-10$ & $1015(14.34)$ & $91(6.89)$ & 0 \\
$11-20$ & $968(13.67)$ & $117(8.86)$ & $601(59.33)$ \\
$21-40$ & $3681(51.99)$ & $815(61.74)$ & $403(39.78)$ \\
$40+$ & $1416(20)$ & $197(22.5)$ & $9(0.89)$ \\
\hline \multicolumn{4}{c}{1320} \\
\hline
\end{tabular}

As shown in table -I Accidental deaths in age group of $0-10$ years were $14.34 \%$, in age group 1120 years were $13.67 \%$, in $21-40$ years were $51.99 \%$ \& in 41 years \& above those were $20 \%$. Homicidal death in age group 0-10 years were $6.89 \%$, in age group $11-20$ years were $8.86 \%$, in age group $21-40$ years were $61.74 \%$ \& in age group 41 years and above those were $22.5 \%$. Suicidal death 0-10 years no case was recorded, suicidal deaths in age group 11-20 years were $59.33 \%$, in age group $21-40$ years were $39.78 \%$ and 41 years and above those were $0.89 \%$.

Table II: Nature of death by sex

\begin{tabular}{ccccc}
\multicolumn{5}{c}{$\mathbf{n = 9 4 1 3}$} \\
\hline Sex & Nature of death & Total \\
& Accidental & Homicidal & Suicidal & \\
\hline Male & $5898(83.31)$ & $966(73.18)$ & $269(26.55)$ & $7133(75.78)$ \\
Female & $1182(16.69)$ & $354(26.82)$ & $744(73.45)$ & $2280(24.22)$ \\
\hline
\end{tabular}

Accidental Deaths (83.31\%) \& Homicidal Deaths (73.18\%) were higher in male than females. Suicidal Deaths were more in females $(73.45 \%)$ than males (26.55\%). (Table- II)

Table III: Nature of death by religion

\begin{tabular}{ccccc}
\multicolumn{5}{c}{$\mathbf{n = 9 4 1 3}$} \\
\hline Religion & Nature of death & Total \\
& Accidental & Homicidal & Suicidal & \\
\hline Muslim & $6514(92)$ & $1267(96)$ & $952(94)$ & $8733(92.78)$ \\
Hindu & $496(7)$ & $40(3)$ & $51(5)$ & $587(6.24)$ \\
Others & $70(1)$ & $13(1)$ & $10(1)$ & $93(0.98)$ \\
\hline
\end{tabular}

* Figures in the parenthesis indicate Percentage

\section{Discussion}

As just observed, most countries have a legal procedure for investigating deaths which are not obvious natural disease ${ }^{4}$. Those deaths which are criminal, suspicious, accidental, suicidal, sudden and unexpected, unexplained or in any way not due to natural causes must be reported for medicolegal investigation ${ }^{4}$.

In this study unnatural deaths were more common in male than female which is similar to the other study. But different from the reports of Rahman AKMS et $\mathrm{al}^{5}$ who had found that homicidal death were more common than other (Accidental \& Suicidal). Homicidal and Accidental deaths were higher in male than female because male are more exposed to external environment than female. Out of all unnatural deaths, Accidental deaths were higher than others, like our neighboring country India. According to a study conducted by The National Transportation Planning and Research center of New Delhi \& Trivandram, in every 4 minutes a person is killed or injured in Road accident in India which has a network of 15 , 00,000 roads. The study pointed out that the number of accidents per lakh population varies from 5.39 in Assam to 63.72 in Maharashtra. In case of accident rate per 100 sq. km area Kerala had the highest figure with 16.85, followed by West Bengal with 15.98.Accident number per $1000 \mathrm{~km}$ of Road length was the highest in Maharashtra, 242 against 168.87 in Guzrat and 145.17 in Tamilnadu. Bangladesh is characterized by high birth rate, high mortality and morbidity rates and high rate of population. According to 1871 cencus it was 22.79 million, this increase to 35.6 million in 1931, 59.85 in 1951 and 107.99 in 1991. Out of these total population major are Muislims, 13\% of total population are Hindus, Buddhist and Christian. Our study pointed out that number of accident per lakh population in our country was $5.32 \%$. It was found that all unnatural deaths were very common in the age between 2140 years. This is due to the fact that it is most active period of life in both sexes. Suicidal deaths were higher in female than male. This is possible because due to lower socio economic condition, lack of education, dowry system, females were 
mentally and physically tortured regularly which stimulate the female to commit suicide. About $71.3 \%$ of cases we got the history of torture by husband and his family members for recovery of dowry in our country. Action to prevent accidents or resultant trauma is becoming ever more important is public health since technological development is modern societies is accompanied by an increased risk of accident deaths ${ }^{7}$.

\section{Conclusion}

In the light of this study, it is obvious that accidental deaths were more common among the all other categories of unnatural deaths in Dhaka city. Homicidal and suicidal deaths were also a major portion among the other unnatural deaths. So all possible steps of measures should be carried out to prevent those unnatural deaths to improve the situation.

\section{References}

1. Reddy KS Narayan. The Essentials of forensic Medicine and Toxicology ; Suguna Devi K, $24^{\text {th }}$ Edition, 2005; P122.

2. Babapulla CJ. Colombage SM; Shan mugathas S. Pattern of causes of death seen in judicial post mortem examinations.Proceedings of the Kandy Society of Medicine 1984; 7: 34-35.

3. Ahmed M. Rahman M. and Hossain M. Pattern of unnatural death in two district. TAJ. 1992; 5: 65-66.

4. K. Park. Park's Text book of preventive and social Medicine; Bharot $\mathrm{n} / \mathrm{s}$ Banarsidas publishers, $20^{\text {th }}$ Edition, 2009; P-353.

5. Knight Bernard. Simpson's Forensic Medicine; Arnold, $11^{\text {th }}$ Edition, 1997; P-14.

6. Rahman AKMS et al. Characteristics of unnatural deaths recorded at Mymensingh Medical College Morgue. Mym. Med. Journal. 1992; 1: 25-27.

7. Rashid KM. Rahman Mahmudur. Hyder Sayeed, Rashid, Khabir, Hyder's Text book of Community Medicine And public health; RHM Publishers, $4^{\text {th }}$ Edition, 2008; P-370. 